\title{
The Effectiveness of Ondansetron in Preventing Hypotension and Bradicardia in Spinal Anestesia
}

\author{
Albert*, Akhyar Hamonangan Nasution**, Qadri Fauzi Tanjung** \\ * Resident of Anaesthesiology and Intensive Therapy, Faculty of Medicine, Universitas Sumatera Utara, Medan, Indonesia \\ **Departement of Anaesthesiology and Intensive Therapy, Faculty of Medicine, Universitas Sumatera Utara, Medan, Indonesia
}

Abstract

\section{Background:}

Spinal anesthesia was typically used for elective surgery and was associated with the incidence of hypotension and bradycardia due to sympathetic block. Bezold-Jarisch reflex (BJR) is a reflex that contributes to cause hypotension and bradycardia mediated by serotonin receptors (5-HT3). Ondansetron, a 5-HT3 receptor antagonist, is assumed to inhibit the effect of serotonin and BJR.

$>$ Aim:

To assess the effectiveness of ondansetron in preventing hypotension and bradycardia after spinal anesthesia.

\section{> Methods:}

This study was an experimental study with a "posttest with control group" design conducted at Haji Adam Malik General Hospital and USU Hospital in February 2020 to June 2020. Seventy study subjects who underwent lower abdominal, gynecology, lower extremities under spinal anesthesia were selected by consecutive sampling and were divided into 2 groups. Group 1 received $4 \mathrm{mg}$ ondansetron, while group 2 received 2 cc normal saline, both interventions were given 30 minutes before spinal anesthesia

\section{$>$ Results:}

Baseline and minimum mean arterial pressure were higher in the ondansetron group at 97.07 \pm 5.09 mmHg and $85.20 \pm 6.48 \mathrm{mmHg}$ compared to the control group (p-value $<0.05$ ). Hypotension was more common in the control group $(\mathbf{5 1 . 4 3 \%})$ than in ondansetron group $(20 \%)$ (p-value $<0.05)$. The mean baseline and minimum heart rate were higher in the ondansetron group at 81,09 $\pm 9,62 \mathrm{bpm}$ and $79.7 \pm 8.75 \mathrm{bpm}$ compared to the control group $(\mathbf{p}<0.05)$. The incidence of bradycardia was more common in the control group $(\mathbf{1 7 . 1 \%})$ compared to the ondansetron group (2.9\%) (pvalue $<0.05)$.

\section{$>$ Conclusion:}

Ondansetron $4 \mathrm{mg}$, given intravenously, is effective in lowering the incidence of hypotension and bradycardia under spinal anesthesia.

\section{INTRODUCTION}

Spinal anesthesia is the simplest, most effective regional anesthetic technique and has been widely used throughout the world. ${ }^{1}$ Hypotension and bradycardia are sequelae of spinal anesthesia with a proportion of $15 \%$ to $33 \%$ of cases, whereas bradycardia occurs in about $10 \%$ of patients. In another study it was found that in more than 1800 patients who received spinal anesthesia, 26\% experienced complications, the majority in the form of hypotension $(16 \%)$. Several studies have stated that the incidence reaches $8-33 \%$. $^{2}$

Hypotension usually occurs in the first 1 to 15 or 20 minutes after subarachnoid injection. The difference in prevalence can be influenced by patient history, comorbidities and the anesthetic technique used. The general definition of hypotension is related to systolic blood pressure. The underlying mechanism is venous and arterial vasodilation caused by sympathetic block of anesthetics extending to 2-6 cephalad dermatomes from the initial sensory level of spinal anesthesia. Because $75 \%$ of the total blood volume resides in the venous system, venodilation causes venous pooling and decreased venous return. In addition, the absence of a compensatory response to reflex tachycardia or excessive vagal activity is also a contributing factor to hypotension. ${ }^{2}$

Nowadays, ondansetron is a popular drug and is believed to prevent hypotension and bradycardia in patients receiving spinal anesthesia. Ondansetron is a selective 5HT3 receptor antagonist used as an antiemetic (nausea and vomiting) after surgery and radiotherapy. Serotonin receptor type 5-HT3 is found on both peripheral terminal vagal nerves and is concentrated in the chemoreceptor trigger zone in the postrema area. Ondansetron acts on the nucleus tractus solitarius at the 5-HT3 receptor, blocking bradycardia chemoreflex and inhibiting baroreflex and BJR responses. ${ }^{3-5}$

Based on Rashad and Farmawy study, it was concluded that patients who received ondansetron $4 \mathrm{mg}$ intravenously before subarachnoid block significantly reduced the incidence of hypotension and the use of vasopressors and preloading ondansetron intravenously 4 or $6 \mathrm{mg}$ and rapid fluid loading decreased the incidence of hypotension and nausea and stabilized hemodynamic. ${ }^{6,7}$

Keywords:- Ondansetron, Hypotension, Bradycardia, Spinal Anesthesia. 


\section{METHODS}

This study is a clinical trial with a "Posttest with Control Group" research design. In this study, the intervention and control groups were found to assess the effectiveness of ondansetron against the incidence of hypotension and bradycardia. This research was conducted in the operating room of Haji Adam Malik General Hospital Medan and the Universitas Sumatera Utara Hospital Medan (USU Hospital). This research was conducted from February 2020 to June 2020. The study population was all patients who underwent electivescheduled surgical procedures for lower abdomen, urology, gynecology and lower limbs and used spinal anesthesia.
The sample of this study is part of the study population that meets the inclusion and exclusion criteria. Data analysis was performed using the help of a computer program, namely SPSS (Statistical Package for Social Science). Demographic data are arranged in a frequency distribution table. Inferential data analysis to test the hypothesis using Chi square if the data is normally distributed and Fisher's Exact Test if the data is not normally distributed. Bivariate data for categorical and numeric variables were analyzed using the independent $\mathrm{T}$ test if the data were normally distributed, whereas if the data were not normally distributed, they were analyzed using the Mann-Whitney test. The data is considered significant if the $\mathrm{p}$ value is $<0.05$

\section{RESULT}

In this study, the research subjects were 70 people who were divided into 2 groups, namely the ondansetron group and the control group (normal saline). All study subjects were patients who underwent elective lower abdominal, gynecology, and lower extremity surgery using spinal anesthesia.

\begin{tabular}{|c|c|c|c|}
\hline Characteristic & $\begin{array}{l}\text { Ondansetron } \\
\text { Group }\end{array}$ & $\begin{array}{l}\text { Control } \\
\text { Group }\end{array}$ & $\mathrm{p}$-value \\
\hline Age $($ Mean \pm SD, years $)$ & $43,26 \pm 14,71$ & $46,4 \pm 11,08$ & $0,056^{*}$ \\
\hline \multicolumn{3}{|c|}{$\operatorname{Gender}(\mathrm{n}, \%)$} & \\
\hline Man & $21(60 \%)$ & $28(80 \%)$ & \multirow{2}{*}{$0,001 * *$} \\
\hline Woman & $14(40 \%)$ & $7(20 \%)$ & \\
\hline Body Weight (Mean \pm SD, kilograms) & $61,94 \pm 10,67$ & $57,77 \pm 8,96$ & $0,494 *$ \\
\hline \multicolumn{3}{|c|}{$\operatorname{ASA}(\mathbf{n}, \%)$} & \multirow{3}{*}{$0,016 * *$} \\
\hline ASA 1 & $5(14,3 \%)$ & $2(5,7 \%)$ & \\
\hline ASA 2 & $30(85,7 \%)$ & $33(94,3 \%)$ & \\
\hline \multicolumn{3}{|c|}{ Procedure $(n, \%)$} & \multirow{5}{*}{$0,136^{* *}$} \\
\hline General surgery & $7(20 \%)$ & $3(8,6 \%)$ & \\
\hline Urology & $20(57,1 \%)$ & $20(57,1 \%)$ & \\
\hline Orthopedic & $5(14,3 \%)$ & $9(25,7 \%)$ & \\
\hline Gynecology & $3(8,6 \%)$ & $3(8,6 \%)$ & \\
\hline
\end{tabular}

*T-independent test

**Chi-square test

Table 1:- Demographic Data Table

Based on table 1, the mean age of subjects in the ondansetron group was younger than the control group, namely $43.26 \pm 14.71$ years and $46.4 \pm 11.08$ years. The proportion of men in the ondansetron group was greater than that of women as much as $21(60 \%)$ and $14(40 \%)$. The same proportion was also found in the control group, namely male as much as $28(80 \%)$ and female as much as 7 $(20 \%)$.

The mean body weight of research subjects in the ondansetron and control groups was $61.94 \pm 10.67 \mathrm{~kg}$ and $57.77 \pm 8.96 \mathrm{~kg}$. Based on ASA grade, most of the study subjects in both groups had ASA 2 physical status with 30 $(85.7 \%)$ people in the ondansetron group and $33(94.3 \%)$ people in the control group. ASA 1 had a smaller proportion with $5(14.3 \%)$ people in the ondansetron group and $2(5.7 \%)$ in the control group.

In the ondansetron group, the most common surgical procedures were urology surgery as many as $20(57.1 \%)$, followed by general surgery as much as 7 (20\%), orthopedic as much as $5(14.3 \%)$ and gynecology as many as $3(8,6 \%)$. Different proportions were found in the control group with the most surgical procedures, namely 20 urology surgeries $(57.1 \%)$, followed by 9 orthopedic $(25.7 \%), 3$ general surgeries $(8.6 \%)$, and 3 gynecology $(8.6 \%)$. 
ISSN No:-2456-2165

\begin{tabular}{|c|c|c|c|}
\hline MAP & $\begin{array}{c}\text { Ondansetron } \\
\text { Group }\end{array}$ & $\begin{array}{c}\text { Control } \\
\text { Group }\end{array}$ & p-value \\
\hline Baseline $(\mathrm{mmHg})$ & $97,07 \pm 5,09$ & $97,00 \pm 5,49$ & $0,402^{*}$ \\
\hline Minimal $(\mathrm{mmHg})$ & $85,20 \pm 6,48$ & $81,59 \pm 7,75$ & $0,038^{*}$ \\
\hline
\end{tabular}

*T-independent test

Table 2:- Effectiveness of Ondansetron in Preventing Hypotension and Bradycardia in Spinal Anesthesia

The mean MAP at baseline and minimal was higher in the ondansetron group with value of $97.07 \pm 5.09 \mathrm{mmHg}$ and $85.20 \pm$ $6.48 \mathrm{mmHg}$ compared to the control group (normal saline) with a baseline MAP of 97.00 $\pm 5.49 \mathrm{mmHg}$ and minimal MAP 81.59 $\pm 7.75 \mathrm{mmHg}$. The comparison of the mean MAP between the two groups was statistically significant with a $\mathrm{p}$ value $<0.05$.

\begin{tabular}{|c|c|c|c|}
\hline Group & Hypotension(n,\%) & Not hypotension(n, \%) & P-value \\
\hline Ondansetron & $7(20 \%)$ & $28(80 \%)$ & $0,006^{*}$ \\
\hline Control & $18(51,43 \%)$ & $17(48,57 \%)$ & $70(100 \%)$ \\
\hline Total & $25(35,71 \%)$ & $45(64,29 \%)$ & \\
\hline
\end{tabular}

*Chi-square test

Table 3:- Comparison of Hypotension Incidence

In Table 3. showed that the incidence of hypotension was more prevalent in the control group (normal saline) as many as 18 $(51.43 \%)$ cases, while in the ondansetron group only 7 (20\%) cases. Therefore, there were $28(80 \%)$ of the study subjects who did not experience hypotension were found in the ondansetron group compared to 17 (48.57\%) in the control group. A total of 25 cases ( 7 cases in the ondansetron group, 18 cases in the control group) required intravenous administration of ephedrine $6 \mathrm{mg}$. The effectiveness of ondansetron administration with the incidence of hypotension was statistically significant with a $p$ value $<0.05$.

\begin{tabular}{|c|c|c|c|}
\hline $\begin{array}{c}\text { Heart Rate (Rerata } \pm \text { Standar } \\
\text { Deviasi) }\end{array}$ & $\begin{array}{c}\text { Ondansetron } \\
\text { Group }\end{array}$ & $\begin{array}{c}\text { Control } \\
\text { Group }\end{array}$ & P-value \\
\hline Baseline & $85,6 \pm 8,12$ & $81,09 \pm 9,62$ & $0,306^{*}$ \\
\hline Minimal & $79,7 \pm 8,75$ & $71,4 \pm 11,32$ & $0,001^{*}$ \\
\hline
\end{tabular}

*T-independent test

Table 4:- Comparison of Average Heart Rate

Comparison of mean heart rate at baseline and minimal was higher in the ondansetron group with value of $85.6 \pm 8.12$ times / minute and $79.7 \pm 8.75$ times / minute compared to the control group (normal saline) with a baseline heart rate of $81.09 \pm 9.62$ beats / minute and a minimum heart rate of $71.4 \pm 11.32$ beats / minute. Comparison of mean heart rate was statistically significant with $\mathrm{p}$ value $<0.05$.

\begin{tabular}{|c|c|c|c|}
\hline Group & Bradycardia (n, \%) & Not Bradycardia (n, \%) & P-value \\
\hline Ondansetron & $1(2,9 \%)$ & $34(97,1 \%)$ & $0,046^{*}$ \\
\hline Normal saline & $6(17,1 \%)$ & $29(82,6 \%)$ & $709100 \%)$ \\
\hline Total & $7(10 \%)$ & $63(90 \%)$ & 7 \\
\hline
\end{tabular}

*Chi-square test

Table 5:- Comparison of Bradycardia Incident

Based on Table 5, it was showed that the control group (normal saline) had more bradycardia incidents with $6(17.1 \%)$ cases, while the ondansetron group had only 1 (2.9\%) case. Research subjects who did not experience bradycardia were more in the ondansetron group as many as 34 (97.1) cases, while the control group was 29 (82.9\%) cases. The number of cases requiring $0.5 \mathrm{mg}$ of atropine was the same as the number of cases of bradycardia in both groups. The effectiveness of preoperative ondansetron use on the incidence of bradycardia was statistically significant with a $\mathrm{p}$ value $<0.05$.
IV. CONCCLUSION

Intravenous ondansetron $4 \mathrm{mg}$ can significantly reduce the incidence of hypotension in spinal anesthesia. Ondansetron can significantly reduce the incidence of bradycardia in spinal anesthesia. Ondansentrone can also reduce the need for vasopressor drugs in spinal anesthesia, but not as a single drug. 


\section{REFERENCES}

[1]. Butterworth JF, Mackey DC, Wasnick, JD. Lokal Anesthestics in Morgan \& Mikhail's Clinical Anesthesiology. $6^{\text {th }}$ edition. New York: McGraw-Hill Lange Medical Books: 2018, 263-76.

[2]. Marashi, SM, Omid, SS. Mohammadi SS, Aghajani Y, Movafegh A. Comparing Two Different Doses of Intravenous Ondansetron with Placebo on Attenuation of Spinal-Induced Hypotension and Shivering. Anesth Pain Med. 2014, 4 (2): 1-5.

[3]. Dergacheva, O., Kamendi, H., Wang, X., Pinol, R., Frank, J., Jameson, H., Gorini, C. and Mendelowitz, D. The Role of 5-HT3 and Other Excitatory Receptors in Central Cardiorespiratory Responses to Hypoxia: Implications for Sudden Infant Death Syndrome. Pediatric Research. 2009, 65(6): 625-30.

[4]. Rashad MM, Farmawy MS. Effects of Intravenous Ondansetron and Granisetron on Hemodynamic Changes and Motor and Sensory Blockade Induces by Spinal Anesthesia in Parturients Undergoing Caesarean Section. Egypt J Anaesth 2013, 29: 369-74.

[5]. Griddine, A. dan Bush, J. Ondansetron. 2019. Available at: https://www.ncbi.nlm.nih.gov/books/NBK499839/ [Accessed 22 Nov. 2019].

[6]. Meng et al. Efficacy of Prophylactic Intravenous Ondansetron on The Prevention of Hypotension during Cesarean Delivery: a Dose-Dependent Study. Int J Clin Exp Med. 2014, 7: 5210-16.

[7]. Trabelsi W, Romdhani C, Elaskri H, Sammoud W, Bensalah M, Labbene I, et al. Effect of Ondansetron on The Occurrence of Hypotension and on Neonatal Parameters during Spinal Anesthesia for Elective Caesarean Section : A Prospective, Randomized, Controlled, Double-blind Study. Anesthesiol Res Pract. 2015: 15(8): 61. 